\title{
Editorial
}

\section{The scientific approach to defeating Covid-19 disease}

\author{
Adamson S. Muula
}

Editor-in-Chief, Malawi Medical Journal and School of Public Health and Family Medicine and ACPEHEM, University of Malawi, Blantyre, Malawi

\author{
'What's in a name? That which we call a rose, By any other \\ name would smell as sweet."
}

Spoken by Juliet in Romeo and Juliet, Act 2 Scene 2

Many of us have heard and said that the best approach to defeating the Severe Acute Respiratory Syndrome Corona Virus 2 (SARS-Cov2) and novel Corona virus disease of 2019 (Covid-19) is to let public bealth and science guide the response. Others have invoked both public health and science.. They have said that public health or science should drive the (national or global) response.

The Australian Curriculum Assessment and Reporting Authority says that science is the "ability to use scientific knowledge, understanding, and inquiry skills to identify questions, acquire new knowledge, explain science phenomena, solve problems and draw evidence-based conclusions in making sense of the world, and to recognise how understandings of the nature, development, use and influence of science help us make responsible decisions and shape our interpretations of information."

One of the few Latin words that I learned early in my life is definire, from which the English "define" and "definition" come from. The literal translation of definire is "to set bounds or limits". A boundary includes some things and excludes others. So when people talk about science, one should be interested in what is being included just as what is being excluded. It appears to me that without an agreement on what definition to use, we could be talking about different things and therefore we are bound to have different expectations as to what "science" will help us achieve. The Australian "definition" presented above is helpful in some regards but still invites more questions as to how we should use science in our fight against Covid-19.

In 1990, this was when I was 18 years old, I enrolled at Chancellor College (Chanco) of the University of Malawi as an undergraduate "science" student. At registration, I subscribed for English (all first year students had to take English), Chemistry, Biology, Mathematics and Physics. This was what being a science student entailed. In the subsequent year, I subscribed for Statistics and Computing, Biology, Chemistry, Physics and Philosophy. At this stage, English was not allowed for "Science" students. Subsequently, I proceeded to my third year where I took courses in Biology, Chemistry and Philosophy. I was still a science student, even though there was no Mathematics and no Physics. My philosophy classes were conveniently held in the professor's office (the late Didier Kaphagawani). The three of us (there was one other student in my class) met twice a week to go through different concepts and calculations in philosophy. Interestingly, my colleagues who continued to take several of the first year "science" courses (at higher level, viz Chemistry,
Physics, Chemistry, Biology, Mathematics) considered themselves to being more scientific than us who had now embraced philosophy. I knew this because my friends did not hide their displeasure to my betrayal against the scientific community to which we should have all belonged. In any case, mixing chemistry and philosophy introduced impurities to "pure science". I had been a victim of proselytization. As far as they were concerned, there could not be multiple sciences. Science was chemistry, biology, mathematics, physics, statistics and computer science. I was only glad that "burning at the stakes" was no longer an option for heretics.

\section{Is Medicine an Art or Science?}

Studying philosophy was good and obviously one of my life's regrets, (by the way I have a few regrets).is that I left my philosophy classes in preference to medical school. In medical school, the first essay question that was given to us was to discuss whether medicine as a discipline was an art or a science. I read a bit about the topic and eventually wrote my essay vacillating between two opposing ideas. I concluded that the practice of medicine was both an art and a science. How I wish I could have written that it was neither!

Medicine as an art got messed up with the Flexner report of 1915! My suggestion is that Flexner's Report and his other writings and thoughts be made mandatory reading for first year medical students. Medicine was categorized as a profession. The scientific base of medicine deserved prominence. In part, Abraham Flexner (1866-1959) identified six characteristics of a profession and its professionals: (1) professions involve essentially intellectual operations with large individual responsibility; (2) they derive their raw material from science and learning; (3) this material they work up to a practical and definite end; (4) they possess an educationally communicable technique (their own language); (5) they tend to self-organization; and (6) they are becoming increasingly altruistic in motivation. Point number 6 seems to be a problematic one in today's Malawi, where increasing altruism is challenged especially by people who join professions when perhaps we can suggest they should not have. not by choice.

If we go back to how to solve problems such as these, we will want to first agree on a definition what is art, and what science is. Let me suggest that should we find out that medicine is an art, we may also have to entertain the question as to whether the fight against Covid-19 should include art and not just science. One definition of art is that it is "the expression or application of human creative skill and imagination." There are certainly other definitions of what art is.

\section{The scientific approach to Covid-19}

"It [science] is not perfect. It is only a tool. But it is by far the best tool we have, self-, ongoing, [and] applicable to everything. It has two rules. 
First: there are no sacred truths; all assumptions must be critically examined; arguments from authority are worthless. Second: whatever is inconsistent with the facts must be discarded or revised." Carl Sagan

I have had the misfortune of conversing with young and ambitious high schoolers and their parents who suggest that because they are intelligent, then they must choose a career in the sciences. Some young people also gravitate to the study of medicine for the simple reason that they can amass $A^{*}$ grades very easily. Others think that since they cannot make friends easily, then they have a career in the sciences. I will try not to judge people as what they decide to do, to become or not become is entirely their choice. I will only argue that the perception as to what science is or is not is often incorrect (this could be judgmental as well) with its attendant harm to the individual and/or society.

Contrast to the study of biology, chemistry or physics that I referred to above, to be scientific means that one follows a specific approach when doing things. One of the things that scientists do is to carefully observe issues. Often observations are done within the ambit of research. It is important to note that it is not only scientists who conduct research. Rather, scientists conduct scientific research, meaning that it is systematic. When scientists make decisions there is a need to be systematic. This is not to suggest that decisions cannot be made haphazardly. They can in fact, only that doing so is not scientific. This also does not mean that scientists make scientific decisions all the time. It is important therefore for the public to be aware that just because a decision has been made by a scientist, then it means that the decision is scientific. Nothing can be further from the truth. If scientists follow the scientific approach, then they are making scientific decisions. The bottom line is that to be scientific, it is not the individual or people making decisions that matters most, but the approach. Science is a systematic approach to the discovery of knowledge and/or decision making based on a set of rules that defines what is acceptable knowledge.

Much of what I studied in my philosophy classes was Philosophy of Science. I may have to once again define what I understood about Philosophy of Science.. It was a set of rules that define what is acceptable, and the use of empirical knowledge. I would not think that this understanding almost thirty years ago has not evolved. Why there is likely to have been an evolution (or evolutions) to what philosophy of science has been, many philosophers of science address the same four basic questions: (1) When is something true? (2) If we have more than one explanation, how can we tell which one is better? (3) How can we put what we know into practice? and (4) Why do we do something the way we do it? As we battle Covid-19, I propose we continue to be systematic and as often as practical attempt to answer the four questions listed above. In agreement with Carl Edward Sagan's (November 9, 1934- December 20, 1996) second rule of science: whatever does not agree with the facts is wrong and must be changed or rejected completely. Further, in terms of Covid-19, knowing what is true (however truth is defined) is painfully important, otherwise we become quacks (that is if we are not already).

\section{The role of theory}

Behavioural science is critical to the fight against Covid-19. This sentence has been written intentionally as a truism. I would not be offended if someone were to ask how do I know that behavioural science is critical. They may even argue that it is not. That notwithstanding, behavioral scientists are often interested in understanding how people interact with each other at different levels. They want to understand as much about people and human phenomena (handwashing, physical distancing, masking, drinking ginger teas). Such understanding invites theory which is more or less a summary of "facts" to explain a phenomenon. Theories make facts comprehensible, they symbolise or represent the real world in which we live and behave. Trying to change human behavior, and in this case, in the fight against Covid-19 is like going to sea without maps. It makes the task a thousand times harder! An understanding of available theories or creation of new ones is indispensable to our fight! Again quoting Sagan, "Extraordinary claims require extraordinary evidence." Some of us do fear that while some have been forthcoming with extraordinary claims, the evidence has not been extraordinary. The absence of theory in dealing with Covid-19 is not just reckless but horrifying.

\section{Community Participation is key}

Efforts to defeat Covid-19 will be made further harder if there is no systematic and lukewarm community participation. But what is a community? What is participation? Perhaps much more granular and useful is the question of what sort of community participation will afford us greater gains? Communities may be categorized by geography or social status, by function or objective. With respect to participation, the works of Belasco, Alutto and others from the 1960's remain helpful. Around the same time Arnstein in 1969 came up with the typology of participation which included: manipulation, therapy, informing, consultation, placation, partnership, delegated power and citizen control. Every time I hear someone saying that there is the participation of such and such a person or a group, my question almost always is: which participation?

\section{Conclusions}

As a write this article (in fact a manuscript which becomes an article once published) on Sunday 23rd August 2020, the Covid-19 statistics (counting from the 2nd April 2020 when the first case for Malawi was reported) were thus: 32 new cases on 23rd August out of 592 tests conducted, 42,607 tests conducted so far, 5414 total confirms SARS-Cov 2 infections, 3012 recoveries and 168 deaths in total and no death on 23rd August 2020. Any death is regrettable and I do not wish to be insensitive by saying that 168 deaths is nothing. At national level however, we can only come up with the following suggestions: 1 ) we are likely dealing with a different SARS-Cov 2 than our colleagues faced in Europe; 2) we have a different people than those in Europe; 3) we have a different environment than that in Europe; 4) we are doing our things so well here than others need to learn from us; 5) our infection or deaths rates would have been even lower had we been diligent in what we are doing, and 6) Most of the above.

\section{Bibliography}

Arnstein, S. A ladder of citizen participation. Journal of the American Institute of Planners; 1969: 35 (4) : 216-224

Australian Curriculum Assessment and Reporting Authority. Australian Curriculum. Accessed 21st August 2020 from: https:// www.australiancurriculum.edu.au/f-10-curriculum/science/ glossary/?letter $=\mathrm{S}$

Beck AH. The Flexner Report and the standardization of American medical education. JAMA 2004; 291(17): 2139-2140. 
Belasco JA, Alutto JA. Organizational impact of teacher negotiations. Sagan Carl. Contact. New York: Simon and Schuster; 1985. Industrial Relations 1969; 9: 67-79

Belasco JA, Alutto JA, Greene F. A case analysis of negotiation behavior in an urban school systems, 1969; 2: 22-39 